\title{
Human Proteins with Affinity for Dermatan Sulfate Have the Propensity to Become Autoantigens
}

\author{
Jung-hyun Rho, ${ }^{*}$ Wei Zhang, ${ }^{* \dagger}$ \\ Mandakolathur Murali, ${ }^{\ddagger}$ Michael H.A. Roehrl, ${ }^{\S}$ \\ and Julia Y. Wang* \\ From the Department of Medicine,* Channing Laboratory, \\ Brigham and Women's Hospital, and the Department of \\ Pathology, ${ }^{\ddagger}$ Massachusetts General Hospital, Harvard Medical \\ School, Boston, Massachusetts; the Department of \\ Gastroenterology, ${ }^{\dagger}$ Guiyang Medical College, Guiyang, Guizhou, \\ China; and Department of Pathology and Laboratory Medicine, ${ }^{\S}$ \\ Boston Medical Center, Boston University School of Medicine, \\ Boston, Massachusetts
}

The mystery of why and how a small, seemingly disparate subset of all self molecules become functional autoantigens holds a key to understanding autoimmune diseases. Here and in a companion article in this issue, we show that affinity of self molecules to the glycosaminoglycan dermatan sulfate (DS) is a common property of autoantigens and leads to a specific autoreactive B-1a cell response. Autoimmune ANA/ENA reference sera react preferentially with DS affinity-fractionated cellular proteins. Studying patients with autoimmune diseases, we discovered patient-specific complex autoantigen patterns that are far richer and more diverse than previously thought, indicating significant pathological heterogeneity even within traditionally defined clinical entities, such as systemic lupus erythematosus. By shotgun sequencing of DS affinity-enriched proteomes extracted from cell lines, we identified approximately 200 autoantigens, both novel and previously linked to autoimmunity, including several well-known families of autoantigens related to the nucleosome, ribonucleoproteins, the cytoskeleton, and heat shock proteins. Using electron microscopy, we recognized direct interaction with dead cells as an origin of autoantigenic association of DS with self molecules. DS affinity may be a unifying property of the human autoantigen-ome (ie, totality of self molecules that can serve as functional autoantingens) and thus provides a promising tool for discovery of autoantigens, molecular diagnosis of autoimmune diseases, and development of cause-spe- cific therapies. (Am J Pathol 2011, 178:2177-2190; DOI: 10.1016/j.ajpath.2011.01.031)

Autoimmune diseases are among the most poorly understood medical conditions, although it is well accepted that they are caused by aberrant immune responses directed at endogenous molecules and tissues of the body. Autoimmune diseases encompass a wide spectrum of clinical presentations, and more than 80 types have been classified, based primarily on systemic or organ-specific involvement. ${ }^{1}$ Common systemic autoimmune diseases include systemic lupus erythematosus (SLE), rheumatoid arthritis, and Sjögren syndrome; localized diseases include type 1 diabetes, multiple sclerosis, and Graves disease. Both precise diagnosis and development of cause-directed therapies remain challenging. A major hurdle has been the lack of understanding of etiologically inciting molecular and cellular events and key pathophysiologic mechanisms that lead to autoimmunity.

A central component of autoimmunity consists of autoantigens, against which the immune system raises autoantibodies and destructive autoreactive cells. Rules that determine the repertoire of possible autoantigens and that differentiate autoantigens from the majority of nonautoantigenic self molecules are at present unknown. Among the tens of thousands of human molecules, only a small fraction $(<1 \%)$ have been observed to serve as autoantigens. ${ }^{1,2}$ At first glance, these autoantigens appear to be a Wunderkammer-a

Supported by grants from the National Institute of Allergy and Infectious Diseases (NIAID-NIH) (J.Y.W.) and the American Cancer Society (grant IRG-72-001-35-IRG to M.H.A.R.). M.H.A.R. is a Faculty Fellow of the Karin Grunebaum Cancer Research Foundation. W.Z. is supported in part by the Chinese Scholarship Council.

Accepted for publication January 25, 2011.

Supplemental material for this article can be found at http://ajp. amjpathol.org and at doi:10.1016/j.ajpath.2011.01.031.

Address reprint requests to Julia Y. Wang, Ph.D., Channing Laboratory, Department of Medicine, Brigham and Women's Hospital, 181 Longwood Ave., Boston, MA 02115; or Michael H.A. Roehrl, M.D., Ph.D., Department of Pathology and Laboratory Medicine, Boston Medical Center, 670 Albany St., Boston, MA 02118. E-mail: julia_wang@rics.bwh.harvard.edu or michael_roehrl@post.harvard.edu. 
collection of curiosities without apparent unifying properties, such as physicochemical properties or functional attributes. ${ }^{1}$ On the other hand, many autoimmune diseases share autoantigen markers and display overlapping clinical symptoms. Certain molecules, such as nuclear proteins and proteins involved in the synthesis and processing of DNA and RNA, are more prone to becoming autoantigens. ${ }^{3}$ Autoimmune diseases also occur more frequently in females. ${ }^{4}$ Notably, autoantibody repertoires appear similar in both human patients and mouse models. ${ }^{5}$ These facts and other evidence suggest that autoantigenic properties of self molecules are governed by rules yet to be uncovered.

Several theories attempt to explain the origin of autoantigens. One popular theory is that autoantigens are derived from apoptotic cells, and that, during cell apoptosis, certain self molecules undergo programmed or spontaneous modifications that render them different from the native self and thus autoantigenic. ${ }^{6}$ Another theory is that of molecular mimicry, ${ }^{7}$ which postulates that an immune response initially aimed at a foreign antigen from a microbial infection also targets a self antigen with shared or very similar epitopes. A similar theory is that of epitope spreading. ${ }^{8}$ A primary immune response triggered by a dominant epitope of a foreign antigen may prompt subsequent responses to other epitopes of the same molecule, and through molecular mimicry of these latter epitopes with self antigens, the immune response would spread from the exogenous antigen to self antigens. A less commonly broached theory is that autoantigens may share certain physicochemical features (not necessarily the conventional epitope per se). For example, long charge-rich coiled-coil segments have been found in various autoantigens. ${ }^{9,10}$

Here and in a companion article in this issue, we propose that affinity to dermatan sulfate (DS) is a unifying property of autoantigens. In the companion article, we demonstrate that DS physically interacts with dead cells and that the resulting DS•autoantigen complexes drive autoreactive B-1a cell responses and autoantibody production in mouse models. ${ }^{11}$ Here, we provide further support for our hypothesis with data from human patients and report the identification of approximately 200 human autoantigens with DS affinity.

\section{Materials and Methods}

\section{ANAVENA Reference and Human Patient Sera}

QUANTA Chek ANA (antinuclear antigen) and ENA (extractable nuclear antigen) reference panels (INOVA Diagnostics, San Diego, CA) comprise well-characterized sera from autoimmune disease patients that are known to react with a variety of specific autoantigens. Additional sera from 36 patients with known autoimmune diseases (such as SLE and Sjögren syndrome) were obtained from the Department of Pathology at Massachusetts General Hospital (Boston, MA) after Institutional Review Board approval (see Supplemental Table S1 at $h$ ttp://ajp.amjpathol. org). The presence of autoantibodies in patient sera was initially surveyed with an INNO-LIA ANA Update test kit (Innogenetics, Gent, Belgium) that detects antibodies against the following autoantigens: $\mathrm{Sm}(\mathrm{SmB}$ and $\mathrm{SmD})$, RNP (RNP-70k, RNP-A, RNP-C), SS-A (Ro52 and Ro60), SS-B/La, centromere (Cenp-B), Scl-70 (DNA topoisomerase I), Jo-1, ribosomal $\mathrm{P}$, and histones.

\section{Cell Culture and Protein Extraction}

A549 and HFL-1 cells were cultured in F-12K medium (Invitrogen, Carlsbad, CA). HEp-2 cells were cultured in Eagle's minimum essential medium. HS-Sultan and WIL2-NS cells were cultured in RPMI-1640 medium. All media were supplemented with $10 \%$ fetal bovine serum and a penicillin-streptomycin-glutamine mixture (Invitrogen). Harvested cells were resuspended in $50 \mathrm{mmol} / \mathrm{L}$ phosphate buffer ( $\mathrm{pH}$ 7.4) containing Roche cOmplete Mini protease inhibitor cocktail (Roche Diagnostics, Indianapolis, IN). Cells were homogenized on ice and then sonicated on ice for 5 minutes. The homogenate was centrifuged, and the supernatant was used as total protein extract. Protein concentrations were measured with the RC DC Protein Assay (Bio-Rad Laboratories, Hercules, CA). All samples were stored at $-80^{\circ} \mathrm{C}$.

\section{DS-Affinity Chromatography}

DS-Sepharose resin was prepared by coupling DS (Sigma-Aldrich, St. Louis, MO) to EAH Sepharose 4B (GE Healthcare, Piscataway, NJ). The resin $(20 \mathrm{~mL}$ ) was washed with distilled water and $0.5 \mathrm{~mol} / \mathrm{L} \mathrm{NaCl}$ and then was mixed with $100 \mathrm{mg}$ of DS dissolved in 10 $\mathrm{mL}$ of $0.1 \mathrm{~mol} / \mathrm{L}$ MES buffer ( $\mathrm{pH}$ 5.0). N-ethyl- $\mathrm{N}$-(3dimethylaminopropyl) carbodiimide hydrochloride (Sigma-Aldrich) was added to a final concentration of $0.1 \mathrm{~mol} / \mathrm{L}$. The mixture was incubated at $25^{\circ} \mathrm{C}$ for 24 hours with end-over-end rotation. After the first $60 \mathrm{~min}$ utes, the $\mathrm{pH}$ was readjusted to 5.0. After the coupling, the resin was washed three times each with a low-pH buffer $(0.1 \mathrm{~mol} / \mathrm{L}$ acetate, $0.5 \mathrm{~mol} / \mathrm{L} \mathrm{NaCl}, \mathrm{pH} 5.0)$ and a high-pH buffer $(0.1 \mathrm{~mol} / \mathrm{L}$ Tris, $0.5 \mathrm{~mol} / \mathrm{L} \mathrm{NaCl}, \mathrm{pH}$ 8.0). The DS-Sepharose resin in $10 \mathrm{mmol} / \mathrm{L}$ phosphate buffer ( $\mathrm{pH}$ 7.4) was packed into a C 16/20 column (GE Healthcare). Fractionation of proteins by DS affinity was performed using a BioLogic Duo-Flow system (Bio-Rad). Typically, $20 \mathrm{mg}$ to $50 \mathrm{mg}$ of protein extract in $40 \mathrm{~mL}$ of $10 \mathrm{mmol} / \mathrm{L}$ phosphate buffer $(\mathrm{pH} \mathrm{7.4}$; buffer A) was loaded onto the DS affinity column at a rate of $1 \mathrm{~mL} /$ minute. The column was washed with $60 \mathrm{~mL}$ of buffer $A$ to elute nonbinding proteins. DS-binding proteins were eluted with sequential $40-\mathrm{mL}$ step gradients containing $0.2,0.4,0.6$, and $1.0 \mathrm{~mol} / \mathrm{L} \mathrm{NaCl}$. Fractions were desalted and concentrated to $0.5 \mathrm{~mL}$ each in 5-kDa cutoff Vivaspin 20 centrifugal filters (Sartorius Stedim Biotech, Aubagne, France). The final protein concentration of each fraction was measured. In some experiments, only two step gradients $(0.5$ and 1.0 $\mathrm{mol} / \mathrm{L} \mathrm{NaCl}$ ) were used. 


\section{1-D and 2-D Gel Electrophoresis}

For 1-D gel electrophoresis, $8 \mu \mathrm{g}$ to $20 \mu \mathrm{g}$ of proteins were loaded per lane and separated by SDS-PAGE with $4 \%$ to $12 \%$ NuPAGE Novex Bis-Tris gels (Invitrogen) with MES or MOPS (morpholine propane sulfonic acid) running buffer. For 2-D gel electrophoresis, $50 \mu \mathrm{g}$ to $100 \mu \mathrm{g}$ of proteins were cleaned with the ReadyPrep 2-D cleanup kit (Bio-Rad), redissolved in $185 \mu \mathrm{L}$ of ReadyPrep rehydration/sample buffer (Bio-Rad) and separated on 11-cm IPG strips ( $\mathrm{pH} 3$ to 10; Bio-Rad) using a Protean isoelectric focusing cell (Bio-Rad). In some experiments, 7-cm IPG strips ( $\mathrm{pH} 3$ to 10 or $\mathrm{pH} 3$ to 6 ) were used with $120 \mu \mathrm{L}$ of rehydrated sample. The focused strips were equilibrated with SDS-PAGE equilibration buffers I and II (Bio-Rad). Proteins were separated along the second dimension using $8 \%$ to $16 \%$ Criterion Tris- $\mathrm{HCl}$ gradient gels (Bio-Rad). Fixed gels were stained with fluorescent SYPRO Ruby (Bio-Rad) for 16 hours and imaged on a Typhoon 9410 scanner (GE Healthcare). Images were analyzed with PDQuest 7.4.0 software (Bio-Rad). Gels subjected to Western blot analysis were stained with BioSafe Coomassie Blue G250 (Bio-Rad).

\section{Western Blotting with ANA/ENA Reference or Patient Sera}

Proteins from 1-D or 2-D gels were transferred to polyvinylidene difluoride membranes and blocked with $2 \%$ bovine serum albumin, $1 \%$ casein, and $0.5 \%$ Tween 20 in Tris-buffered saline $(\mathrm{pH} 7.4)$ at $25^{\circ} \mathrm{C}$ for 1 hour. Membranes were incubated with test serum (diluted 1:1000 or $1: 2000$ ) in blocking buffer at $25^{\circ} \mathrm{C}$ for 1 hour. After three washes with Tris-buffered saline containing $0.5 \%$ Tween 20 , membranes were incubated with $0.2 \mu \mathrm{g} / \mathrm{mL}$ goat anti-human IgG conjugated with horseradish peroxidase (Santa Cruz Biotechnology, Santa Cruz, CA) at $25^{\circ} \mathrm{C}$ for 1 hour. Membranes were developed using enhanced chemiluminescence Western blotting substrate (Pierce; Thermo Fisher Scientific, Rockford, IL).

\section{Protein Identification by Mass Spectrometry}

Mass spectrometric (MS) sequencing was performed at the Taplin Biological Mass Spectrometry Facility (Harvard Medical School). Selected protein spots from 1-D or 2-D PAGE gels were excised and cut into $1-\mathrm{mm}^{3}$ pieces. ${ }^{12}$ Gel pieces were dehydrated with acetonitrile, dried in a speed-vac concentrator, and rehydrated at $4^{\circ} \mathrm{C}$ for 45 minutes in $50 \mathrm{mmol} / \mathrm{L} \mathrm{NH} \mathrm{NCO}_{3}$ containing $12.5 \mathrm{ng} / \mu \mathrm{L}$ modified sequencing-grade trypsin (Promega). Tryptic peptides were separated on a nano-scale $\mathrm{C}_{18}$ HPLC capillary column and analyzed after electrospray ionization in an LTQ linear ion-trap mass spectrometer (Thermo Fisher Scientific, West Palm Beach, FL). ${ }^{13}$ Peptide sequences and protein identities were assigned by matching protein or translated nucleotide databases with the measured fragmentation pattern using SEQUEST software, version 27 (revision 12) (Therma Fisher Scientific). Peptides were required to be fully tryptic peptides with XCorr values of at least $1.5\left(1^{+}\right.$ion $), 1.5\left(2^{+}\right.$ion $)$, or 3.0
( $3^{+}$ion). All data were manually inspected. Only proteins with $\geq 2$ independent peptide matches were considered positively identified.

\section{Immunoprecipitation}

Patient serum samples demonstrating strong and wellseparated bands on Western blots were used to determine the identities of the recognized autoantigens. Protein extracts from HEp-2 or WIL2-NS cells were fractionated by DS-affinity chromatography. Patient-specific autoantigens present in these fractions were enriched by immunoprecipitation with patient serum, separated by 1-D or 2-D electrophoresis in duplicate gels, and reactivity with patient serum was verified using Western blot analysis. Immunoprecipitation was performed with a ProFound coimmunoprecipitation kit (Pierce; Thermo Fisher Scientific), and antibodies in patient sera were covalently immobilized onto the resin. Before coupling, antibodies were typically purified from $100 \mu \mathrm{L}$ of patient serum using a Melon gel IgG purification kit (Pierce; Thermo Fisher Scientific). In some experiments, protein A-Sepharose resin was used to noncovalently immobilize antibodies in patient sera. Protein extracts were absorbed with protein A-Sepharose to remove proteins that bind to protein $A$ and then were incubated with autoantibody-bound protein A-Sepharose at $25^{\circ} \mathrm{C}$ for 1 hour. The mixture was centrifuged to precipitate autoantigen $\bullet$ autoantibody $\bullet$ protein A-Sepharose complexes. The complexes were dissociated by SDS-PAGE and examined using Western blot analysis. Reactive protein spots or bands were excised from duplicate gels and sequenced by tandem MS.

\section{Quantification of Immunoglobulins}

DS-specific IgM and IgG in patient sera were measured by enzyme-linked immunosorbent assay. ${ }^{11}$ Nunc MaxiSorp 96-well plates were coated with $0.1 \mathrm{mg} / \mathrm{mL}$ DS or $2.5 \mu \mathrm{g} / \mathrm{mL}$ goat anti-human $\mathrm{F}\left(\mathrm{ab}^{\prime}\right)_{2}$ at $4^{\circ} \mathrm{C}$ overnight. Wells were blocked with $1 \%$ bovine serum albumin at $25^{\circ} \mathrm{C}$ for 1 hour. Patient sera were diluted 100 -fold for measurement of DS-specific antibodies and 2000-fold for measurement of total Ig. IgG and IgM were detected by alkaline phosphatase-conjugated goat anti-human IgG and $\lg \mathrm{M}$, respectively.

\section{Electron Microscopy}

WIL2-NS cells were cultured in Dulbecco's modified Eagle's medium containing 10\% fetal bovine serum (DMEM-10) with $40 \mu \mathrm{g} / \mathrm{mL}$ DS-biotin conjugate (in-house synthesized) for 3 days. Cells were fixed with $4 \%$ paraformaldehyde at $25^{\circ} \mathrm{C}$ for 30 minutes and processed as described. ${ }^{11} \mathrm{Sec}-$ tions of cells were stained with goat anti-biotin conjugated to 20-nm gold particles and examined with a JEOL 1200EX transmission electron microscope (JEOLO USA, Peabody, $\mathrm{MA})$. 
A
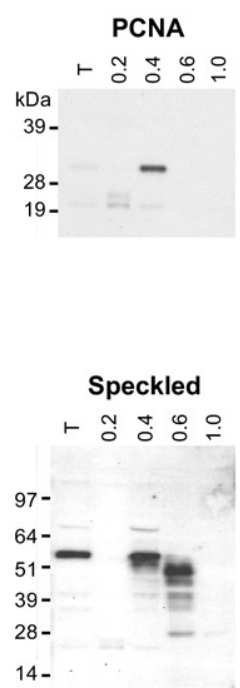

Sm, RNP, SS-A, SS-B

$\vdash$ ก̃

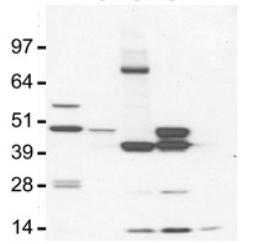

B

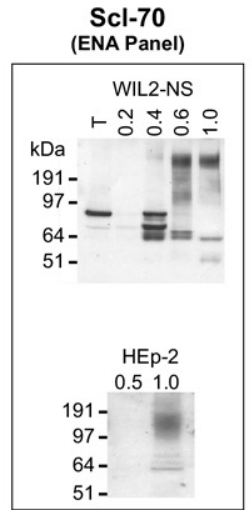

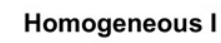

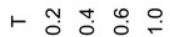

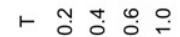

$51-$

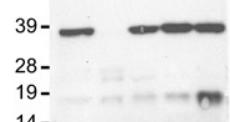

14 -
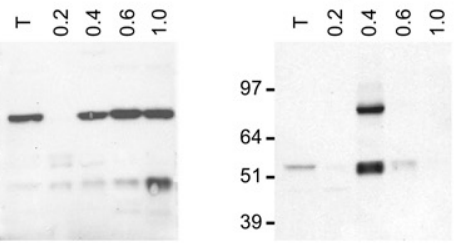

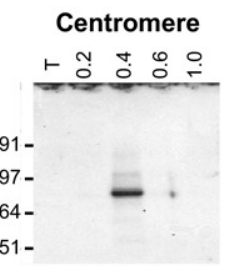

SS-A

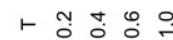
$64-$

SS-A, SS-B

$\vdash$ กั

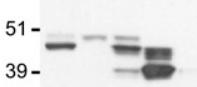

28-

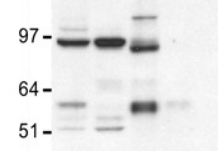

$39-$

\section{Homogeneous II

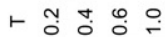

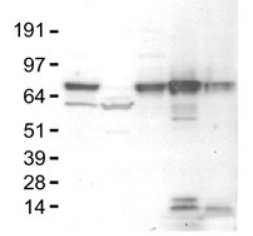

RNP

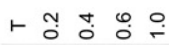

$191-$

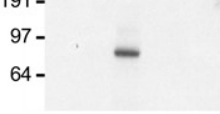

SS-B
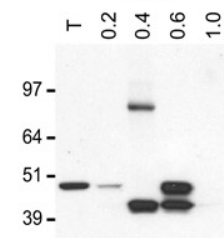

Figure 1. A: Classic ANA/ENA autoantigens are characterized by affinity to DS. Proteome extracts from WIL2-NS cells were fractionated on DS-affinity columns; $10 \mu \mathrm{g}$ of total proteins were loaded per lane. Gels were blotted with individual ANA or ENA reference serum (each gel is labeled with the nominal reference serum specificity). B: DS interacts with Scl-70•DNA complexes. Left: ENA and ANA panels. Proteome extracts from WIL2-NS or HEp-2 cells were fractionated by DS affinity and blotted with two different Scl-70 reference sera. Note that smeared bands at high molecular weight were detected in DS-binding fractions. Right: For the ANA panel, WIL2-NS proteins eluted with 0.6 $\mathrm{mol} / \mathrm{L} \mathrm{NaCl}$ were treated with PNGase F, DNase I, or RNase A and analyzed by electrophoresis and using Western blot analysis with Scl-70 reference serum. Only after digestion with DNase I did the smeared bands disappear, whereas the band corresponding to Scl-70 increased in intensity, suggesting that the smear corresponds to Scl-70 $\bullet$ DNA complexes. Lane labels: T, total un fractionated extract; numbers above lanes indicate the molar concentration of $\mathrm{NaCl}$ used for the respective elution step.

\section{Results}

\section{Classic ANA/ENA Autoantigens Are Characterized by Affinity to $D S$}

To test the hypothesis that autoantigens are characterized by affinity to DS, we first examined a panel of wellknown ANA (antinuclear antigen) and ENA (extractable nuclear antigen) autoantigens. Autoantibodies against ANAs and ENAs are hallmarks of systemic autoimmune diseases, and their detection is a major screening test in clinical practice. ${ }^{14}$ We extracted the proteomes of various human cell lines, fractionated them on a DS-affinity column with increasing concentrations of salt, and interrogated for abundance of ANA or ENA autoantigens in these fractions by blotting with ANA or ENA reference sera. Proteins eluted from the DS-affinity column with step gradients of $0.2 \mathrm{~mol} / \mathrm{L}, 0.4$ to $0.6 \mathrm{~mol} / \mathrm{L}$, or $1 \mathrm{~mol} / \mathrm{L} \mathrm{NaCl}$ were considered not/weakly DS-binding, DS-binding, or tightly DS-binding, respectively (Figure 1; see also Supplemental Figure S1 at http://ajp.amjpathol.org).

Because a single cell line may not express a complete repertoire of autoantigens, we examined the proteomes from five human cell lines representing different tissue types: HEp-2 (epithelial cell line used diagnostically for ANA immunofluorescence assays), A549 (epithelial), HFL-1 (mesenchymal), HS-Sultan (lymphoid), and WIL2-NS (lymphoid). Protein extracts from the different cell lines typically revealed distinct autoreactive patterns, illustrating the differential presence of various autoantigen repertoires in these cells (Figure 1; see also 

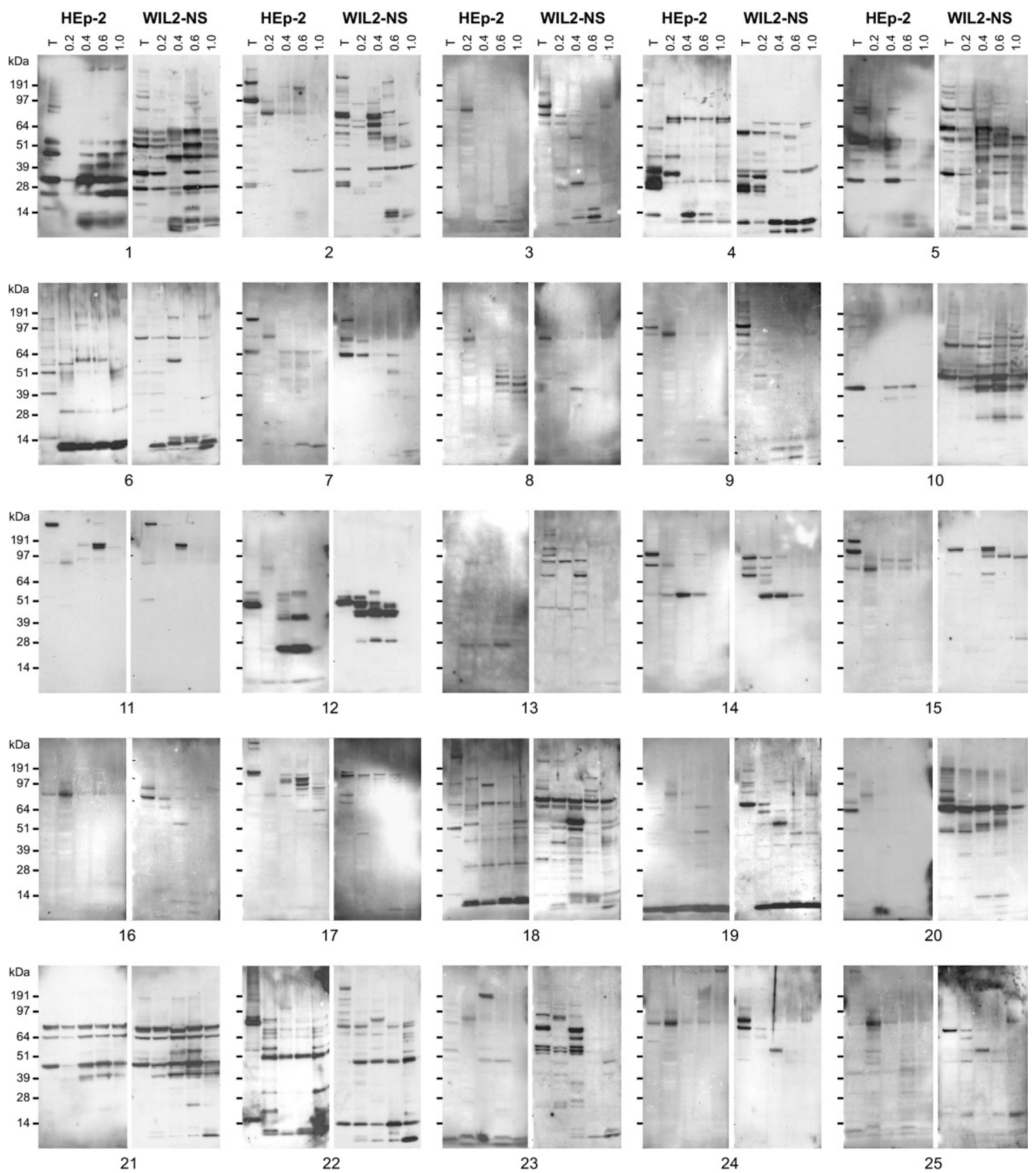

Figure 2. Autoantigen profiling in autoimmune disease shows unexpected diversity. Proteins extracted from HEp-2 or WIL2-NS cells were DS-affinity fractionated (T, total unfractionated extract; numbers above lanes indicate the molar concentration of $\mathrm{NaCl}$ used for the respective elution step); $8 \mu \mathrm{g}$ of total proteins were loaded per lane. Autoantigens were detected using Western blot analysis with individual patient serum (gels for patients 1 to 25 are shown). The $\sim 80-\mathrm{kDa}$ band frequently appearing in not/weakly DS-binding $(0.2 \mathrm{~mol} / \mathrm{L} \mathrm{NaCl})$ fractions was identified as Ig $\gamma-1$ chain C (see Supplemental Figure S3D at bttp://ajp.amjpathol. org), which reacts with the secondary anti-IgG used for blotting and thus corresponds to a false positive band.

Supplemental Figure S1 at http://ajp.amjpathol.org). Of the five cell lines, WIL2-NS cells gave typically rise to the highest number of autoantigens and associated autoreactive bands (Figure 1A).

Remarkably, all autoantigens recognized by ANA and ENA reference antisera were present in the DSbinding or tightly DS-binding fractions (Figure 1; see also Supplemental Figure S1 at http://ajp.amjpathol. org). Some autoantigens were detectable only after DSaffinity fractionation; for example, PCNA (proliferating cell nuclear antigen) was detectable only in DS-binding fractions, not in unfractionated or nonbinding proteins. Similarly, autoantigens reactive with anti-RNP or anti-centromere serum were detected only in DS-binding, not in total unfractionated or nonbinding fractions. Thus, DS-affinity fractionation significantly enriched these autoantigens to detectable levels.

Total unfractionated protein extracts typically showed a single major autoantigen band corresponding to the expected specificity of each ANA or ENA reference se- 
Table 1. Tandem MS Sequencing of Selected DS-binding Proteins from 1-D/2-D PAGE Gels

\begin{tabular}{|c|c|c|c|c|c|c|}
\hline UniProt ID & Protein ID* & $\begin{array}{l}\text { Peptide } \\
\text { matches }\end{array}$ & $\begin{array}{c}\text { MS/MS } \\
\text { coverage (aa) }\end{array}$ & Cell line & PAGE & $\mathrm{NaCl}^{\star *}$ \\
\hline P05455 & LA (La autoantigen, SS-B) & 15 & $148 / 408(36.3 \%)$ & HS-Sultan & 2-D & $0.4-1.0 \mathrm{M}$ \\
\hline \multirow[t]{2}{*}{ P12956 } & KU70 (Ku autoantigen protein p70, XRCC6) & 3 & $45 / 608(7.4 \%)$ & HEp-2 & $1-D$ & $0.4-0.6 \mathrm{M}$ \\
\hline & KU70 & 21 & $257 / 608(42.3 \%)$ & HEp-2 & $1-D$ & $0.4-0.6 \mathrm{M}$ \\
\hline P13010 & KU86 (Ku autoantigen protein p86, XRCC5) & 10 & $109 / 731(14.9 \%)$ & HEp-2 & $1-D$ & $0.4-0.6 \mathrm{M}$ \\
\hline \multirow[t]{2}{*}{ P19338 } & NUCL (nucleolin) & 12 & $122 / 709(17.2 \%)$ & HEp-2 & $1-D$ & $0.4-0.6 \mathrm{M}$ \\
\hline & $\mathrm{NUCL}$ & 14 & $161 / 709(22.7 \%)$ & A549 & 2-D & $0.4-0.6 \mathrm{M}$ \\
\hline P06748 & NPM (nucleophosmin) & 16 & $172 / 294(58.5 \%)$ & A549 & $2-D$ & $0.4-0.6 \mathrm{M}$ \\
\hline P05388 & RLA0 (60S acidic ribosomal protein P0) & 10 & $120 / 317(37.9 \%)$ & HS-Sultan & 2-D & $0.4-1.0 \mathrm{M}$ \\
\hline Q9UNX3 & RL26L (60S ribosomal protein L26-like 1) & 4 & $33 / 145(22.8 \%)$ & A549 & 2-D & $0.4-0.6 \mathrm{M}$ \\
\hline P46777 & RL5 (60S ribosomal protein L5) & 16 & $110 / 296(37.2 \%)$ & HEp-2 & $1-D$ & $0.5-1.0 \mathrm{M}$ \\
\hline Q96A08 & H2B1A (histone H2B type 1-A) & 5 & $42 / 126(33.3 \%)$ & A549 & 2-D & $0.4-0.6 \mathrm{M}$ \\
\hline P33778 & H2B1B (histone H2B type 1-B) & 4 & $25 / 125(20.0 \%)$ & A549 & $2-\mathrm{D}$ & $0.4-0.6 \mathrm{M}$ \\
\hline Q6FGB8 & Histone $\mathrm{H} 4$ & 7 & $54 / 103(52.4 \%)$ & WIL2-NS & 2-D & $0.4-0.6 \mathrm{M}$ \\
\hline Q01105 & SET (HLA-DR-associated protein II) & 9 & $138 / 290(47.6 \%)$ & A549 & 2-D & $0.4-0.6 \mathrm{M}$ \\
\hline P39687 & $\begin{array}{l}\text { AN32A (acidic leucine-rich nuclear phosphoprotein } 32 \text { family } \\
\text { member A) }\end{array}$ & 16 & $130 / 249(52.2 \%)$ & A549 & $2-\mathrm{D}$ & $0.4-0.6 \mathrm{M}$ \\
\hline Q92688 & $\begin{array}{l}\text { AN32B (acidic leucine-rich nuclear phosphoprotein } 32 \text { family } \\
\text { member B) }\end{array}$ & 11 & $57 / 251(22.7 \%)$ & A549 & $2-D$ & $0.4-0.6 \mathrm{M}$ \\
\hline P16989 & DBPA (DNA-binding protein A) & 4 & $40 / 372(10.8 \%)$ & HEp-2 & 2-D & $0.5-1.0 \mathrm{M}$ \\
\hline \multirow[t]{2}{*}{ O60812 } & HNRCL (hnRNP core protein C-like 1) & 9 & $73 / 293(24.9 \%)$ & A549 & 2-D & $0.4-0.6 \mathrm{M}$ \\
\hline & HNRCL & 5 & $41 / 293(14.0 \%)$ & WIL2-NS & 2-D & $0.4-0.6 \mathrm{M}$ \\
\hline P07910 & HNRPC (heterogeneous nuclear ribonucleoproteins C1/C2) & 8 & $95 / 306(31.0 \%)$ & A549 & 2-D & $0.4-0.6 \mathrm{M}$ \\
\hline Q16629 & SFRS7 (splicing factor, arginine/serine-rich 7) & 3 & $30 / 238(12.6 \%)$ & WIL2-NS & 2-D & $0.4-0.6 \mathrm{M}$ \\
\hline Q15393 & SF3B3 (splicing factor 3B subunit 3) & 11 & $139 / 1217(11.4 \%)$ & HEp-2 & $1-D$ & $0.4-0.6 \mathrm{M}$ \\
\hline P12814 & ACTN1 (alpha-actinin-1) & 28 & $334 / 892(37.4 \%)$ & HEp-2 & $1-D$ & $0.4-0.6 \mathrm{M}$ \\
\hline O43707 & ACTN4 (alpha-actinin-4) & 22 & $270 / 911(29.6 \%)$ & HEp-2 & 1-D & $0.4-0.6 \mathrm{M}$ \\
\hline Q13813 & SPTA2 (spectrin alpha chain, brain) & 17 & $233 / 2472(9.4 \%)$ & HEp-2 & 1-D & $0.4-0.6 \mathrm{M}$ \\
\hline \multirow[t]{2}{*}{ P27797 } & Calreticulin & 19 & $209 / 417(50.1 \%)$ & HEp-2 & $2-D$ & $0.5-1.0 \mathrm{M}$ \\
\hline & Calreticulin & 15 & $180 / 417(43.2 \%)$ & HEp-2 & 2-D & $0.2-0.4 \mathrm{M}$ \\
\hline \multirow[t]{3}{*}{ Q07021 } & $\begin{array}{l}\text { C1QBP (complement component } 1 \mathrm{Q} \text { subcomponent-binding } \\
\text { protein, mitochondrial) }\end{array}$ & 3 & $58 / 282(20.6 \%)$ & HEp-2 & $2-D$ & $0.5-1.0 \mathrm{M}$ \\
\hline & C1QBP & 12 & $171 / 282(60.6 \%)$ & A549 & 2-D & $0.4-0.6 \mathrm{M}$ \\
\hline & C1QBP & 8 & $115 / 282(40.8 \%)$ & HS-Sultan & 2-D & $0.4-1.0 \mathrm{M}$ \\
\hline Q13310 & PABP4 (poly(A)-binding protein 4) & 16 & $136 / 644(21.1 \%)$ & HEp-2 & $1-D$ & $0.5-1.0 \mathrm{M}$ \\
\hline Q9H361 & PABP3 (poly(A)-binding protein 3) & 9 & $77 / 631(12.2 \%)$ & HEp-2 & 1-D & $0.5-1.0 \mathrm{M}$ \\
\hline \multirow[t]{3}{*}{ P11021 } & GRP78 (heat shock 70 kDa protein 5) & 51 & $401 / 654(61.3 \%)$ & A549 & 2-D & $0.5-1.0 \mathrm{M}$ \\
\hline & GRP78 & 16 & $214 / 654(32.7 \%)$ & HEp-2 & $1-D$ & $0.4-0.6 \mathrm{M}$ \\
\hline & GRP78 & 34 & $336 / 654(51.4 \%)$ & HEp-2 & $2-\mathrm{D}$ & $0.2-0.4 \mathrm{M}$ \\
\hline \multirow[t]{3}{*}{ P11142 } & HSP7C (heat shock cognate 71 kDa protein) & 15 & 193/646 (29.9\%) & HEp-2 & 2-D & $0.5-1.0 \mathrm{M}$ \\
\hline & $\mathrm{HSP7C}$ & 6 & $91 / 646(14.1 \%)$ & HEp-2 & $2-D$ & $0.5-1.0 \mathrm{M}$ \\
\hline & HSP7C & 20 & $252 / 646$ (39.0\%) & HS-Sultan & $2-D$ & $0.4-1.0 \mathrm{M}$ \\
\hline \multirow[t]{2}{*}{ P38646 } & GRP75 (heat shock 70 kDa protein 9) & 25 & $338 / 679(49.8 \%)$ & HEp-2 & 2-D & $0.5-1.0 \mathrm{M}$ \\
\hline & GRP75 & 19 & $250 / 679(36.8 \%)$ & HS-Sultan & $2-D$ & $0.4-1.0 \mathrm{M}$ \\
\hline P22314 & UBA1 (ubiquitin-like modifier-activating enzyme 1) & 15 & $216 / 1058(20.4 \%)$ & HEp-2 & $1-D$ & $0.4-0.6 \mathrm{M}$ \\
\hline P06733 & ENOA (alpha-enolase) & 12 & $128 / 433(29.6 \%)$ & HEp-2 & $1-D$ & $0.4-0.6 \mathrm{M}$ \\
\hline P28072 & PSB6 (proteasome subunit beta type-6) & 13 & $137 / 239(57.3 \%)$ & A549 & $2-D$ & $0.2-0.4 \mathrm{M}$ \\
\hline \multirow[t]{3}{*}{ P21333 } & FLNA (filamin-A) & 11 & $159 / 2646(6.0 \%)$ & HEp-2 & $1-D$ & $0.5-1.0 \mathrm{M}$ \\
\hline & FLNA & 21 & $245 / 2646(9.3 \%)$ & HEp-2 & $1-D$ & $0.4-0.6 \mathrm{M}$ \\
\hline & FLNA & 10 & $135 / 2646(5.1 \%)$ & HEp-2 & $1-D$ & $0.4-0.6 \mathrm{M}$ \\
\hline 075369 & FLNB (filamin-B, thyroid autoantigen) & 17 & $217 / 2602(8.3 \%)$ & HEp-2 & $1-D$ & $0.4-0.6 \mathrm{M}$ \\
\hline Q6P2Q9 & PRP8 (pre-mRNA-processing-splicing factor 8) & 12 & $119 / 2335(5.1 \%)$ & HEp-2 & $1-D$ & $0.4-0.6 \mathrm{M}$ \\
\hline P62306 & RUXF (snRNP-F) & 7 & $27 / 86(31.4 \%)$ & A549 & $2-\mathrm{D}$ & $0.4-0.6 \mathrm{M}$ \\
\hline Q53GF5 & Proteasome subunit alpha type & 13 & $128 / 234(54.7 \%)$ & A549 & 2-D & $0.2-0.4 \mathrm{M}$ \\
\hline P25789 & PSA4 (proteasome subunit alpha type-4) & 20 & $197 / 261(75.5 \%)$ & A549 & $2-D$ & $0.2-0.4 \mathrm{M}$ \\
\hline Q16531 & DDB1 (damage-specific DNA-binding protein 1) & 28 & $295 / 1140(25.9 \%)$ & HEp-2 & $1-D$ & $0.4-0.6 \mathrm{M}$ \\
\hline & PURA (purine-rich single-stranded DNA-binding protein alpha) & 7 & $110 / 322(34.2 \%)$ & A549 & 2-D & $0.4-0.6 \mathrm{M}$ \\
\hline \multirow[t]{3}{*}{ Q04837 } & SSBP (single-stranded DNA-binding protein, mitochondrial) & 10 & $89 / 148(60.1 \%)$ & A549 & 2-D & $0.4-0.6 \mathrm{M}$ \\
\hline & SSBP & 10 & $93 / 148(62.8 \%)$ & WIL2-NS & 2-D & $0.4-0.6 \mathrm{M}$ \\
\hline & SSBP & 5 & $52 / 148(35.1 \%)$ & WIL2-NS & 2-D & $0.4-0.6 \mathrm{M}$ \\
\hline Q00610 & CLH1 (clathrin heavy chain 1) & 51 & $565 / 1674(33.8 \%)$ & HEp-2 & $1-D$ & $0.4-0.6 \mathrm{M}$ \\
\hline P80723 & BASP1 (brain acid soluble protein 1) & 3 & $49 / 226(21.7 \%)$ & HEp-2 & $2-\mathrm{D}$ & $0.2-0.4 \mathrm{M}$ \\
\hline & FETUA (fetuin A, alpha-2-HS-glycoprotein) & 2 & $13 / 367(3.5 \%)$ & HEp-2 & 2-D & $0.2-0.4 \mathrm{M}$ \\
\hline \multirow{2}{*}{ P07148 } & FABPL (fatty acid-binding protein, liver) & 5 & $67 / 127(52.8 \%)$ & WIL2-NS & $2-D$ & $0.4-0.6 \mathrm{M}$ \\
\hline & FABPL & 3 & $35 / 127(27.6 \%)$ & WIL2-NS & $2-D$ & $0.4-0.6 \mathrm{M}$ \\
\hline Q6ZRT8 & Ubiquitin C & 5 & $43 / 186(23.1 \%)$ & WIL2-NS & $2-D$ & $0.4-0.6 \mathrm{M}$ \\
\hline
\end{tabular}

A complete version of the table, with literature references characterizing the proteins as functional human autoantigens, can be found in the Supplemental Appendix (available at $h$ ttp://ajp.amjpathol.org).

${ }^{*}$ Repeated listing of the same protein indicates that tandem MS sequencing of more than one gel band/spot yielded the same protein identity.

${ }^{*} \mathrm{NaCl}$ concentrations used to wash and elute from DS-affinity resin (eg, 0.4-1.0 M indicates that proteins were eluted with $1.0 \mathrm{M} \mathrm{NaCl}$ after washing with $0.4 \mathrm{M} \mathrm{NaCl}$ ).

rum (Figure 1). After DS-affinity fractionation, however, numerous additional autoantigen bands became detectable that had not previously been known to be recognized by these reference sera. For example, instead of one major band (in unfractionated extract), ANA reference serum (with speckled immunofluorescence reactivity pattern) recognized numerous bands in the $0.4 \mathrm{~mol} / \mathrm{L}$ and $0.6 \mathrm{~mol} / \mathrm{L} \mathrm{NaCl}$ fractions (Figure 1). Similarly, addi- 
Table 2. Tandem MS Sequencing of DS-associating Proteins and Their Known Autoantigenic Propensities

\begin{tabular}{|c|c|c|c|c|}
\hline \multicolumn{3}{|c|}{ Peptide matches* } & \multirow[b]{2}{*}{ UniProt ID } & \multirow[b]{2}{*}{ Protein ID } \\
\hline $\begin{array}{l}\text { 1.0-M NaCl } \\
\text { fraction }\end{array}$ & $\begin{array}{l}0.6-\mathrm{M} \mathrm{NaCl} \\
\text { fraction }\end{array}$ & $\begin{array}{l}0.4-\mathrm{M} \mathrm{NaCl} \\
\text { fraction }\end{array}$ & & \\
\hline & & & & Chromatin-related proteins \\
\hline 6,7 & $5,4,4,6$ & $4,5,5$ & Q6FGB8 & Histone $\mathrm{H} 4$ \\
\hline 5,2 & 5 & & P33778 & Histone $\mathrm{H} 2 \mathrm{~B}$ type 1-B \\
\hline 3 & 2,4 & & Q96A08 & Histone $\mathrm{H} 2 \mathrm{~B}$ type 1-A testis-specific histone $\mathrm{H} 2 \mathrm{~B}$ \\
\hline 2 & 3,4 & & Q96QV6 & Histone $\mathrm{H} 2 \mathrm{~A}$ type $1-\mathrm{A}$ \\
\hline 4 & 2,3 & 2 & Q16695 & Histone $\mathrm{H} 3.4$ \\
\hline 2 & $6,3,2$ & 3 & P16401 & Histone $\mathrm{H} 1.5$ histone $\mathrm{H} 1 \mathrm{~A}$ \\
\hline 2 & 2 & 3 & Q02539 & Histone $\mathrm{H} 1.1$ \\
\hline & 2 & 2,2 & P16403 & Histone $\mathrm{H} 1.2$ histone $\mathrm{H} 1 \mathrm{D}$ \\
\hline & & $6,3,2$ & P49321 & Nuclear autoantigenic sperm protein histone binding protein \\
\hline & & 2 & Q16576 & Histone-binding protein rbbp 7 retinoblastoma-binding protein 7 \\
\hline 2 & 3 & & P16989 & $\begin{array}{l}\text { DNA-binding protein A cold shock domain-containing protein A, single-strand DNA-binding protein } \\
\text { NF-GMB }\end{array}$ \\
\hline 2 & & $3,4,3$ & P53999 & Activated RNA polymerase II transcriptional coactivator p15 \\
\hline 3 & & & Q6PKI6 & YBX1 protein transcription factor \\
\hline 2 & & & Q96E14 & Hypothetical protein RecQ-mediated genome instability protein 2, BLM-associated protein of $18 \mathrm{kDa}$ \\
\hline 2 & $5,5,4$ & & Q01105 & SET phosphatase 2a inhibitor, HLA-DR-associated protein II \\
\hline & $9,10,10$ & & P39687 & $\begin{array}{l}\text { Acidic leucine-rich nuclear phosphoprotein } 32 \text { family member A potent heat-stable protein } \\
\text { phosphatase 2A inhibitor I1PP2A }\end{array}$ \\
\hline & $5,4,5$ & & Q92688 & Acidic leucine-rich nuclear phosphoprotein 32 family member B \\
\hline & $3,2,2$ & & Q9BTT0 & Acidic leucine-rich nuclear phosphoprotein 32 family member $\mathrm{E}$ \\
\hline & 4,2 & 2,3,3 & P55209 & Nucleosome assembly protein 1 -like 1 \\
\hline & 7 & 2 & Q99733 & Nucleosome assembly protein 1-like 4 \\
\hline & 5,2 & $5,3,4$ & P13010 & ATP-dependent DNA helicase 2 subunit $2 \mathrm{Ku}$ autoantigen protein $\mathrm{p} 86$ \\
\hline & 8,2 & $4,12,7$ & P12956 & ATP-dependent DNA helicase 2 subunit $1 \mathrm{Ku}$ autoantigen protein $\mathrm{p} 70$ \\
\hline & 4,3 & $3,3,4$ & P06454 & Prothymosin alpha \\
\hline & 2 & & Q08945 & FACT complex subunit SSRP1 facilitates chromatin transcription complex subunit SSRP1 \\
\hline & 2 & & Q9Y5B9 & FACT complex subunit SPT16 facilitates chromatin transcription complex subunit SPT16 \\
\hline & & $9,6,6$ & Q9UGV6 & High mobility group protein 1 -like 10 \\
\hline & & $5,2,5,3$ & P51858 & Hepatoma-derived growth factor high-mobility group protein 1-like 2 \\
\hline & & 2 & Q75MM1 & Similar to non-histone chromosomal protein HMG-1 \\
\hline & & $3,9,3$ & P49736 & DNA replication licensing factor MCM2 minichromosome maintenance protein 2 homolog \\
\hline & & 3,7 & Q14566 & DNA replication licensing factor MCM6 \\
\hline & & 3,4 & P33991 & DNA replication licensing factor MCM4 \\
\hline & & 2,3 & P25205 & DNA replication licensing factor MCM3 \\
\hline & & 3 & P33992 & DNA replication licensing factor MCM5 \\
\hline & & $3,2,2$ & Q13185 & Chromobox protein homolog 3 heterochromatin protein 1 homolog gamma \\
\hline & & 2 & P83916 & Chromobox protein homolog 1 heterochromatin protein 1 homolog beta \\
\hline & & 3 & P78527 & DNA-dependent protein kinase catalytic subunit \\
\hline & & 3 & P20290 & Transcription factor BTF3 RNA polymerase B transcription factor 3 \\
\hline & & 2 & P35659 & Protein DEK \\
\hline & & $6,5,2$ & P12004 & Proliferating cell nuclear antigen PCNA \\
\hline & & 2 & P11387 & DNA topoisomerase $1 \mathrm{Scl}-70$ \\
\hline & & & & Nucleolar phosphoproteins \\
\hline 4 & $23,17,17,3$ & $3,6,3$ & P19338 & Nucleolin \\
\hline 2 & $6,4,2$ & $2,6,4$ & P06748 & Nucleophosmin \\
\hline & 7,3 & & Q14978 & Nucleolar phosphoprotein p130 nucleolar and coiled-body phosphoprotein 1 \\
\hline & 2 & & Q9BQG0 & Myb-binding protein $1 \mathrm{~A}$ \\
\hline & & & & Nuclear pore complex-related proteins \\
\hline & & 7,3 & 000410 & Importin subunit beta-3 karyopherin subunit beta-3 \\
\hline & & 6 & Q14974 & Importin subunit beta- 1 karyopherin subunit beta- 1 \\
\hline & & 2 & 000505 & Importin subunit alpha-3 karyopherin subunit alpha-3 \\
\hline & & 2 & 043592 & Exportin-T tRNA exportin \\
\hline & & & & Ribonucleoproteins RNPs or ribosomal proteins \\
\hline 2 & 3 & & P05388 & $60 S$ acidic ribosomal protein PO \\
\hline 2,3 & & $3,4,2,2$ & P05387 & $60 S$ acidic ribosomal protein $\mathrm{P} 2$ \\
\hline 7 & 2,3 & & P18124 & $60 S$ ribosomal protein $L 7$ \\
\hline 6 & $7,7,2$ & & P46777 & $60 S$ ribosomal protein L5 \\
\hline 4 & 2,2 & & P62424 & $60 S$ ribosomal protein $L 7 a$ \\
\hline 4 & 2,3 & & Q02878 & $60 S$ ribosomal protein L6 \\
\hline 2 & 2,2 & & Q9NQS8 & Ribosomal protein S3 \\
\hline 2 & 2 & & P62753 & $40 S$ ribosomal protein S6 \\
\hline 2 & 2 & & P15880 & 40 S ribosomal protein S2 S4 \\
\hline 5 & 4 & & P46781 & 40 S ribosomal protein S9 \\
\hline 2 & 2 & & P62244 & $40 \mathrm{~S}$ ribosomal protein $\mathrm{S} 15 \mathrm{a}$ \\
\hline 2 & 3 & & Q6NXR8 & Ribosomal protein S3A \\
\hline 2 & 2 & & P82663 & Ribosomal protein S25 \\
\hline 2 & 3 & & Q6IPX9 & Ribosomal protein S3 \\
\hline 2 & & & Q5T6E0 & Ribosomal protein L15 \\
\hline 2 & & & Q9UNX3 & $60 S$ ribosomal protein L26-like 1 \\
\hline 3 & & & P39023 & $60 S$ ribosomal protein L3 \\
\hline 2 & & & Q07020 & $60 S$ ribosomal protein L18 \\
\hline 2 & & & Q59FI9 & Ribosomal protein L12 variant \\
\hline & 2,2 & 2 & P35268 & $60 S$ ribosomal protein L22 \\
\hline & 2 & & U02032 & Ribosomal protein L23a \\
\hline & 2 & & Q6IRZO & RPL31 protein \\
\hline & 2 & & Q567Q7 & Ribosomal protein L8 \\
\hline & & 3,2 & M77233 & Ribosomal protein S7 \\
\hline 2,3 & $4,6,4$ & $2,6,4$ & P05455 & Lupus La protein SS-B \\
\hline $6,2,2$ & & & Q9H361 & Polyadenylate-binding protein 3 \\
\hline 2 & & & Q13310 & Polyadenylate-binding protein 4 \\
\hline 2 & $8,2,4$ & & P09661 & U2 small nuclear ribonucleoprotein $\mathrm{A}^{\prime}$ \\
\hline & & & & (table continues) \\
\hline
\end{tabular}


$2184 \quad$ Rho et al

AJP May 2011, Vol. 178, No. 5

Table 2. Continued

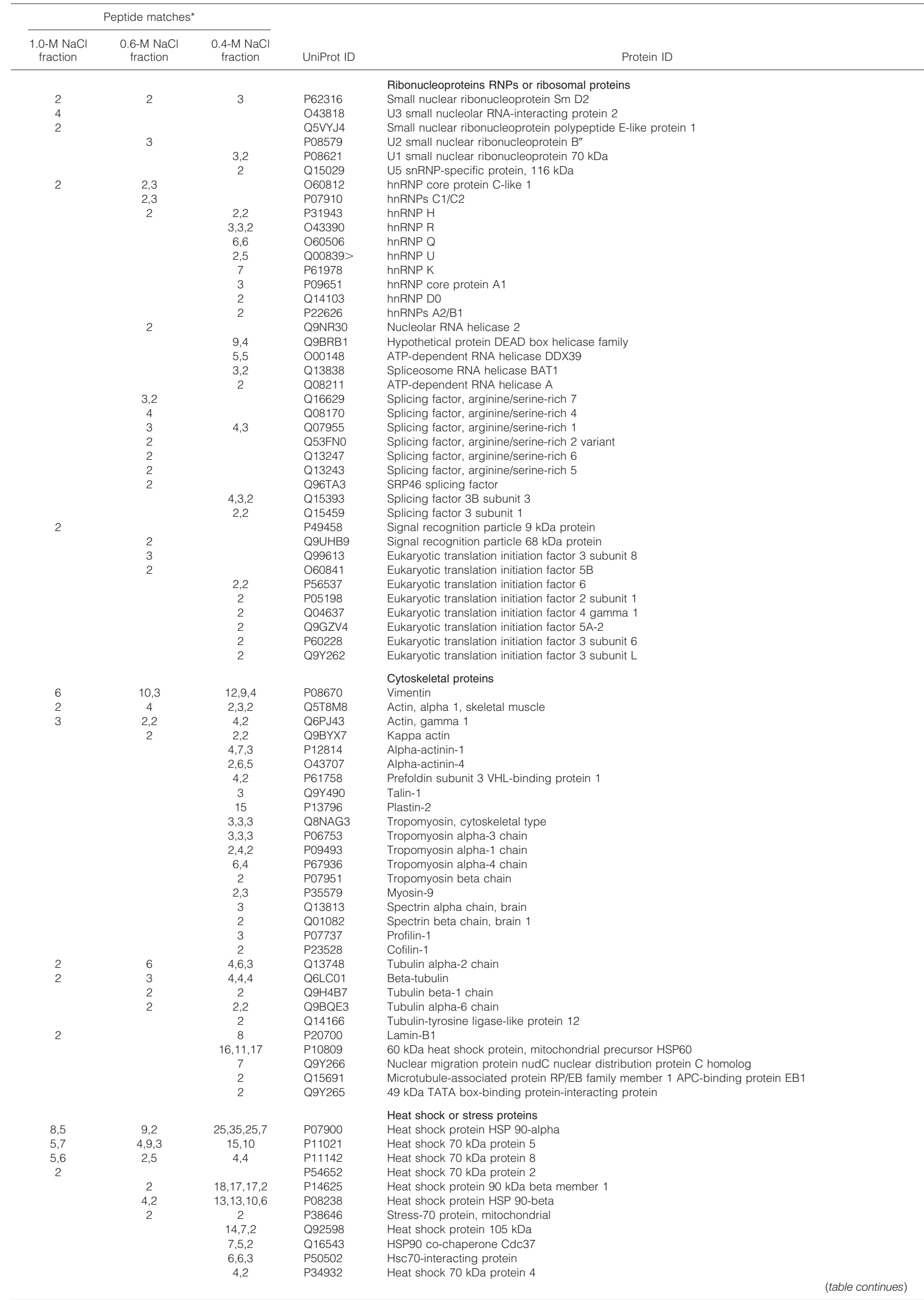


Table 2. Continued

\begin{tabular}{|c|c|c|c|c|}
\hline \multicolumn{3}{|c|}{ Peptide matches* } & \multirow[b]{2}{*}{ UniProt ID } & \multirow[b]{2}{*}{ Protein ID } \\
\hline \multirow[t]{33}{*}{$\begin{array}{l}\text { 1.0-M NaCl } \\
\text { fraction }\end{array}$} & $\begin{array}{l}0.6-\mathrm{M} \mathrm{NaCl} \\
\text { fraction }\end{array}$ & $\begin{array}{l}0.4-\mathrm{M} \mathrm{NaCl} \\
\text { fraction }\end{array}$ & & \\
\hline & & & & Protein processing-related proteins synthesis, folding, degradation \\
\hline & 3 & 2,2 & P29692 & Elongation factor 1-delta \\
\hline & 3 & 2 & P26641 & Elongation factor 1 -gamma \\
\hline & 2 & & P13639 & Elongation factor 2 \\
\hline & & 2 & P24534 & Elongation factor 1-beta \\
\hline & & 4,4 & Q13765 & Nascent polypeptide-associated complex subunit alpha \\
\hline & & $12,7,3$ & P78371 & T-complex protein 1 subunit beta \\
\hline & & $11,11,6$ & P50990 & T-complex protein 1 subunit theta \\
\hline & & $5,6,2$ & P17987 & T-complex protein 1 subunit alpha \\
\hline & & $4,5,2$ & P40227 & T-complex protein 1 subunit zeta \\
\hline & & $4,5,2$ & Q99832 & T-complex protein 1 subunit eta \\
\hline & & 5,9 & P49368 & T-complex protein 1 subunit gamma \\
\hline & & 3,7 & P48643> & T-complex protein 1 subunit epsilon \\
\hline & & 2 & P50991 & T-complex protein 1 subunit delta \\
\hline & & $12,8,8,3$ & P07237 & Protein disulfide-isomerase \\
\hline & & $9,11,9$ & P13667 & Protein disulfide-isomerase A4 \\
\hline & & $6,7,5$ & Q15084 & Protein disulfide-isomerase A6 \\
\hline & & 2 & O43396 & Thioredoxin-like protein 1 \\
\hline & & 2,5 & P28070 & Proteasome subunit beta type- 4 \\
\hline & & 2,4 & P28066 & Proteasome subunit alpha type- 5 \\
\hline & & 3,2 & Q8TAA3 & Proteasome subunit alpha type-7-like \\
\hline & & 3 & P25786 & Proteasome subunit alpha type-1 \\
\hline & & 2 & 014818 & Proteasome subunit alpha type- 7 \\
\hline & & 2 & P61289 & Proteasome activator complex subunit 3 \\
\hline & & 2 & Q53FT5 & Proteasome $26 \mathrm{~S}$ non-ATPase subunit 11 variant \\
\hline & & 2 & P28072 & Proteasome subunit beta type- 6 \\
\hline & & 2,2 & Q9UBE0 & SUMO-activating enzyme subunit 1 \\
\hline & & 2,2 & Q9UBT2 & SUMO-activating enzyme subunit 2 \\
\hline & & 10 & P22314 & Ubiquitin-like modifier-activating enzyme 1 \\
\hline & & 2 & P45974 & Ubiquitin carboxyl-terminal hydrolase 5 \\
\hline & & 2,2 & Q86VP6 & Cullin-associated NEDD8-dissociated protein 1 \\
\hline & & & & Enzymes \\
\hline \multirow[t]{28}{*}{2} & 2 & 4 & P04406 & Glyceraldehyde-3-phosphate dehydrogenase \\
\hline & 3,3 & & Q5U5J2 & Casein kinase 2 , alpha 1 \\
\hline & 2,2 & & P46060 & Ran GTPase-activating protein 1 \\
\hline & 3 & & 015355 & Protein phosphatase $1 \mathrm{G}$ \\
\hline & 4 & & P06733 & Alpha-enolase \\
\hline & 2 & & P60174 & Triosephosphate isomerase \\
\hline & 2 & & P40925 & Malate dehydrogenase, cytoplasmic \\
\hline & 2 & 2 & P00338 & L-lactate dehydrogenase A chain \\
\hline & & 3 & P07195 & L-lactate dehydrogenase $B$ chain \\
\hline & & 4,2 & P30153 & Serine/threonine-protein phosphatase $2 \mathrm{~A} 65 \mathrm{kDa}$ regulatory subunit $\mathrm{A}$ alpha isoform \\
\hline & & $13,15,15,3$ & P55072 & Transitional endoplasmic reticulum ATPase \\
\hline & & 7,3 & 095671 & $\mathrm{~N}$-acetylserotonin O-methyltransferase-like protein \\
\hline & & $3,3,5$ & Q96HY3 & CALM1 protein \\
\hline & & 2 & Q9BRL5 & CALM3 protein \\
\hline & & $3,2,2$ & Q9Y2B0 & Protein canopy homolog 2 \\
\hline & & 2,2 & P14314 & Glucosidase 2 subunit beta \\
\hline & & 2 & P29966 & Myristoylated alanine-rich C-kinase substrate \\
\hline & & 10 & P06576 & ATP synthase subunit beta, mitochondrial \\
\hline & & 6 & P49327 & Fatty acid synthase \\
\hline & & 5 & Q99873 & Protein arginine $\mathrm{N}$-methyltransferase 1 \\
\hline & & 3 & Q9Y4L1 & Hypoxia-upregulated protein 1 \\
\hline & & 3 & Q9UKK9 & ADP-sugar pyrophosphatase \\
\hline & & 2 & P12268 & Inosine-5'-monophosphate dehydrogenase 2 \\
\hline & & 2 & P31939 & Bifunctional purine biosynthesis protein PURH \\
\hline & & 2 & Q01581 & Hydroxymethylglutaryl-coa synthase, cytoplasmic \\
\hline & & 2 & Q9NQW7 & Xaa-Pro aminopeptidase 1 \\
\hline & & 2 & Q15185 & Prostaglandin E synthase 3 \\
\hline & & & & Miscellaneous \\
\hline \multirow[t]{19}{*}{3} & 3 & 3,2 & Q07021 & Complement component $1 \mathrm{Q}$ subcomponent-binding protein, mitochondrial \\
\hline & & $10,9,5,3$ & P27797 & Calreticulin \\
\hline & & 16 & P08133 & Annexin A6 \\
\hline & & 5,5 & P42704 & Leucine-rich PPR motif-containing protein, mitochondrial \\
\hline & & 6,2 & Q12906 & Interleukin enhancer-binding factor 3 \\
\hline & & 4 & Q12905 & Interleukin enhancer-binding factor 2 \\
\hline & & 3 & 000299 & Chloride intracellular channel protein 1 \\
\hline & & $11,9,9,2$ & Q4VJB6 & 14-3-3 protein epsilon isoform transcript variant 1 \\
\hline & & $11,9,7$ & P31946 & 14-3-3 protein beta/alpha \\
\hline & & $7,3,3$ & P61981 & 14-3-3 protein gamma \\
\hline & & $4,5,3$ & Q04917 & 14-3-3 protein eta \\
\hline & & $2,2,2$ & Q6LD62 & 14-3-3 protein \\
\hline & & $2,2,2$ & Q2F831 & $14-3-3$ protein zeta \\
\hline & & $3,2,2$ & Q53S41 & $14-3-3$ protein theta \\
\hline & & 2 & P62258 & $14-3-3$ protein epsilon \\
\hline & & 3 & Q14444 & Caprin-1 \\
\hline & & 2 & Q9NR28 & Diablo homolog, mitochondrial \\
\hline & & 2 & Q9BZZ5> & Apoptosis inhibitor 5 \\
\hline & & 2 & Q8IXQ4 & Lipopolysaccharide-specific response protein 7 \\
\hline
\end{tabular}

A complete version of the table, with literature references characterizing the proteins as a functional human autoantigens, can be found in the Supplemental Appendix (available at $h$ ttp://ajp.amjpathol.org)

*Number of distinctly matched peptides that identify each protein. Four independent experiments (DS-affinity fractionation with tandem MS sequencing) were performed. Only results with positive protein identification ( $\geq 2$ matched peptides) are listed. Hence, up to 4 numbers are shown in each column entry. 
tional autoantigens were revealed by reference antisera with nominal specificities for SS-B, SS-A/SS-B, Scl-70, and ribosomal P. In some cases, autoreactive bands were also detected in the $0.2 \mathrm{~mol} / \mathrm{L} \mathrm{NaCl}$ fraction (Figure 1 ), possibly because of weak affinity of these autoantigens to DS or, particularly when the same bands were also present in higher-salt fractions, because of capacity overloading of the DS-affinity column.

The increased sensitivity of autoantigen detection by DS-affinity enrichment enabled further differentiation of traditional ANA/ENA immunofluorescence reactivity patterns. For example, two reference sera, each with homogeneous reactivity pattern in the HEp-2-based immunofluorescence assay and thus phenotypically indistinguishable, yielded very different underlying autoantigen profiles (Figure 1). Similarly, two reference sera with nominal anti-Scl-70 specificity yielded complicated and distinct profiles (Figure 1B).

These experiments also pointed to a potential mechanism for autoantigenicity of DNA. In addition to discrete protein bands, the two anti-Scl-70 sera reacted with smeared bands at high molecular weight in the DS-binding fractions from both HEp-2 and WIL2-NS proteome extracts (Figure 1B). Scl-70 (topoisomerase I) is an enzyme that unwinds supercoiled DNA by nicking and ligating DNA strands. Only DNase digestion, but not treatment with PNGase F or RNase A, caused the disappearance of the high molecular weight smears, identifying them as Scl-70•DNA complexes (Figure 1B). Thus, DS interacts not only with Scl-70 alone, but also with Scl-70•DNA complexes. In fact, it seems attractive to speculate that DS•Scl-70•DNA ternary complexes may be responsible for the production of autoantibodies to both $\mathrm{Scl}-70$ and DNA.

\section{Autoantigen Profiling in Autoimmune Disease Shows Unexpected Diversity}

We next asked whether autoantigen affinity to DS could be used as a principle for comprehensive profiling of autoantigens in human autoimmune diseases. We collected sera from 36 patients with autoimmune diseases, including SLE and Sjögren syndrome, among others (see Supplemental Table S1 at http://ajp.amjpathol.org). Proteins extracted from HEp-2 or WIL2-NS cells were fractionated by DS affinity, separated by SDS-PAGE, and blotted with individual patient serum (Figure 2 and data not shown).

The unexpectedly complex autoreactive patterns observed were largely unique for each patient (Figure 2). Compared with a limited spectrum of clinical diagnoses (see Supplemental Table S1 at http://ajp.amjpathol.org) and a commercial strip assay (see Supplemental Figure S2 at http://ajp.amjpathol.org) that demonstrated only a small set of autoantigens, our method uncovered a much larger repertoire of autoantigens. The patient-specific autoreactive profiles illustrate an autoantigenic diversity in autoimmune diseases that is much greater than previously thought or currently assayed for. Even within patient groups with similar clinical presentation (eg, patients di- agnosed with SLE), autoantigen profiles were strikingly different (Figure 2; see also Supplemental Table S1 at http://ajp.amjpathol.org).

When unfractionated protein extracts from either HEp-2 or WIL2-NS were used, typically only very few bands reacted with patient sera. After DS-affinity fractionation, however, numerous additional autoreactive bands emerged, particularly in DS-binding fractions. Many patients presented complex patterns with many distinct autoantigens present across the DS-binding fractions (eg, patients 1, 5, 10, 18, and 22) (Figure 2). Without DSaffinity enrichment, this large number of additional autoantigens would not have been detectable.

WIL2-NS proteome extracts generally revealed more reactive bands, and so contained more autoantigens than HEp-2 extracts. For example, serum from patient 10 reacted with two bands using fractionated HEp-2 proteins, but many more bands when proteins from WIL2-NS cells were used (Figure 2). This observation is particularly noteworthy and relevant because virtually all current clinical patient testing, including immunofluorescence pattern description, is based on HEp-2 cells, and thus likely misses a significant number of autoantibodies.

To verify that the newly detected autoreactive bands indeed resulted from specific recognition of autoantigens by patient sera, we characterized selected prominent bands in detail. Sera from patients 11, 12, and 14 (all with speckled HEp-2 ANA immunofluorescence pattern) reacted strongly with distinct bands in DS-binding fractions (Figure 2; see also Supplemental Figure S3, A-C at $h t t p: / /$ ajp.amjpathol.org). Proteins from HEp-2 cells were fractionated by DS affinity, and the specific reactive proteins were further enriched by serum immunoprecipitation and identified by MS sequencing (see Supplemental Figure S3 at http://ajp.amjpathol.org). Serum from patient 11 reacted with two bands in DS-binding fractions $(0.6 \mathrm{~mol} / \mathrm{L}$ $\mathrm{NaCl}$ ), which corresponded to SPTA2 (spectrin $\alpha-I I)$ and PRP8 (U5 snRNP) (upper band) and $\alpha$-actinin- 1 and $\alpha$-actinin-4 (lower band) (see Supplemental Figure S3A at http://ajp.amjpathol.org). Serum from patient 12 reacted with LA (La/SS-B protein) (0.4 to $0.6 \mathrm{~mol} / \mathrm{L} \mathrm{NaCl}$; see Supplemental Figure S3B at http://ajp.amjpathol.org. Serum from patient 14 reacted with BASP1 (brain acid soluble protein 1) and FETUA (fetuin A) (0.4 to $0.6 \mathrm{~mol} / \mathrm{L} \mathrm{NaCl}$; see also Supplemental Figure S3C at $h$ ttp://ajp.amjpathol.org). Of note, all of these proteins serve as well-known autoantigens (Table 1; see also Supplemental Appendix and references therein at $h$ ttp://ajp.amjpathol.org), supporting the usefulness of DS affinity as a tool for enhanced profiling of autoantigens.

We next examined sera from three SLE patients $(1,2$, and 7) to survey possible disease markers. Serum from patient 1 recognized several autoantigens that were detectable only after DS-affinity enrichment (Figure 2). To further characterize these specific autoantigens, DSbinding proteins from WIL2-NS cells were enriched by serum immunoprecipitation. Ten autoantigens were identified by MS sequencing: histones $\mathrm{H} 1.1$ and $\mathrm{H} 1.5, \mathrm{Sm}$ D2, U2 snRNP B", snRNP F, La/SS-B, prothymosin $\alpha$, YBX1, and $60 S$ ribosomal proteins L6 and L5. 
For patient 2, MS sequencing revealed serum specificities for 15 autoantigens, including 5 histones (H2A type 1-A, H4, H2B type 1-B, H1.5, and H2B type 1-C/E/ F/G/I), 7 small nucleoprotein autoantigens (Sm D1, Sm D2, Sm D3, U1 snRNP A, U2 snRNP A', snRNP B/B', and U2 snRNP $B^{\prime \prime}$ ), 2 S100 calcium-binding proteins (A8 and A9), and Ig mu heavy chain binding protein. The results are consistent with a strip screening test that identified reactivity of this patient's serum with $S m B, S m D, R N P$ 70k, RNP-A, RNP-C, and histones (see Supplemental Figure S2 at $h$ ttp://ajp.amjpathol.org).

For patient 7, five autoantigens were identified by MS sequencing: vitamin $\mathrm{K}$-dependent protein $\mathrm{S}$, complement C4-A, C1QBP, H2A type 1-A, and H2B type 1-B. Protein $S$ is a known autoantigen with close links to phospholipid autoantibodies and SLE. ${ }^{15}$

Comparison of these SLE patients shows that patients 1 and 2 share three autoantigens $(H 1.5$, Sm D2, and U2 snRNP $B^{\prime \prime}$ ) and patients 2 and 7 share two autoantigens (H2A type 1-A and H2B type 1-B). Of note, although patients $1,2,7,11,12$, and 14 all displayed a morphologically indistinguishable speckled ANA immunofluorescence pattern on HEp-2 cells, the underlying causative autoantigen repertoires are quite divergent, another finding that highlights significant interindividual autoantigenic diversity in autoimmune diseases.

\section{Autoantigen Repertoire (the Autoantigen-ome)}

Using patient or ANA/ENA reference sera, we demonstrated that autoantigens are preferentially DS-binding. We next asked whether affinity to DS is a unifying physicochemical property of autoantigens (the autoantigen-ome).

To this end, we sought to identify potential autoantigens without use of sera from autoimmune disease patients. First, we characterized a limited number of DSbinding proteins and asked whether they had known autoantigenic propensity. Proteins extracted from several cell lines were fractionated by DS affinity and separated by 1-D or 2-D gel electrophoresis. Discrete bands or spots were then selected based on favorable separation and intensity characteristics and individually sequenced by tandem MS (Table 1; see also Supplemental Appendix and references therein at http://ajp.amjpathol.org).

Using A549 cells as an example, 13 spots from gels with DS-binding proteins were selected after 2-D separation, from which 18 different proteins were identified (Table 1; see also Supplemental Appendix and references therein and Supplemental Figure S4A at $h t t p: / / a j p$. amjpathol.org). Using 1-D gel electrophoresis, 12 bands were sequenced, from which 23 different proteins were identified (Table 1; see also Supplemental Appendix and references therein and Supplemental Figure S4B at http:// ajp.amjpathol.org). Some of these proteins were repeatedly identified from extracts of different cell lines or from different protein bands or spots of the same cell line (Table 1; see also Supplemental Appendix and references therein at http://ajp.amjpathol.org).

All 46 proteins identified in this manner are either previously known autoantigens or have been functionally associated with autoimmune diseases (Table 1; see also the Supplemental Appendix and references therein at http://ajp.amjpathol.org). Well-known autoantigens identified include La (a signature autoantigen in Sjögren syndrome) and the lupus autoantigens Ku70 and Ku86. Other well-established autoantigens include histones, hnRNPs, GRP78, HSP7C, filamin-A, filamin-B, nucleolin, PRP8, $\mathrm{RLAO}$, and $\alpha$-actinin- 1 and -4 . Although some of the remaining proteins have not previously been definitively characterized as autoantigens, most are, nevertheless, at least closely related to autoimmunity. For example, calreticulin shares sequence homology with GRP78 and cross-reacts with anti-Ro/SS-A. ${ }^{16}$ Poly(A)-binding proteins 3 and 4 share sequence homology with La/SS-B. ${ }^{17,18}$

Next, we used a shotgun approach and sequenced pools of proteins fractionated by DS-affinity columns to characterize a much broader repertoire of potential cellular DS-binding autoantigens. Proteins from WIL2-NS cells were used because these cells express many autoantigens (Figure 1). To demonstrate the relative enrichment of autoantigens by DS affinity, we individually sequenced total, unfractionated, and fractionated pools by tandem MS.

Unfractionated proteins yielded the identities of 120 distinct proteins (see Supplemental Table S2 at $h t t p: / /$ ajp.amjpathol.org) from 337 2-D gel spots (see Supplemental Figure S5 and Supplemental Table S3 at http:// ajp.amjpathol.org). Of these 120 proteins, 64 were present in DS-binding fractions (eluting with $0.4,0.6$, or $1 \mathrm{~mol} / \mathrm{L}$ $\mathrm{NaCl}), 29$ were in the $0.2 \mathrm{~mol} / \mathrm{L} \mathrm{NaCl}$ fraction, and 27 were not identified after fractionation. Of the total, 72 (60\%) have previously been characterized as functional autoantigens.

The $0.2 \mathrm{~mol} / \mathrm{L} \mathrm{NaCl}$ fraction (ie, DS nonbinding to weakly binding) yielded 175 protein identities (see Supplemental Table S3 at http://ajp.amjpathol.org and references therein). Among these, 112 proteins were present exclusively in the $0.2 \mathrm{~mol} / \mathrm{L} \mathrm{NaCl}$ fraction, corresponding to nonbinding or weakly DS-binding proteins, whereas 63 were also present in fractions eluted with higher concentrations of $\mathrm{NaCl}(0.4 \mathrm{~mol} / \mathrm{L}$ to $1.0 \mathrm{~mol} / \mathrm{L})$, possibly indicating biochemical heterogeneity due to post-translational modifications or excess of column loading capacity. The most abundant species among these nonbinding proteins $(53 / 112,47.3 \%)$ are enzymes. Of the 112 nonbinding to weakly binding proteins, 44 (39.3\%) have previously been reported to react with autoantibodies. Strikingly, however, among the 63 proteins that were also present in DS-binding fractions, 50 (79.4\%) are known autoantigens, corresponding to a more than twofold relative increase in autoantigenic propensity over the nonbinding to weakly binding group.

A total of 232 DS-binding proteins (eluting with $0.4,0.6$, or $1.0 \mathrm{~mol} / \mathrm{L} \mathrm{NaCl}$ ) were identified (Table 2; see also Supplemental Appendix and references therein at $h t t p: / /$ ajp.amjpathol.org). Among them, 140 (60.3\%) proteins have been previously described as autoantigens (Table 2; see also Supplemental Appendix and references therein at http://ajp.amjpathol.org). Remarkably, these DS-binding proteins cluster into several well-known categories of autoantigens, ${ }^{2}$ including 40 chromatin-related proteins, 68 ribonucleoproteins or ribosomal proteins, 29 cytoskeletal proteins, 11 heat shock proteins, 27 en- 
zymes, 30 protein processing-related proteins, 4 nucleolar phosphoproteins, and 4 nuclear pore complex proteins. In general, proteins with the strongest affinity to DS were histones, ribosomal proteins, heat shock proteins, and cytoskeletal proteins, whereas enzymes and protein processing-related proteins possessed lower affinity to DS (Table 2; see also Supplemental Appendix and references therein and Supplemental Table S3 at http://ajp. amjpathol.org).

Well-known autoantigenic nuclear proteins, such as histones, Scl-70, PCNA, Ro, La, and Ku, were present predominantly in the DS-binding fractions $(0.4 \mathrm{~mol} / \mathrm{L}$ to $1.0 \mathrm{~mol} / \mathrm{L}$ elutions) (Table 2 and Figure 1; see also Supplemental Appendix and references therein and Supplemental Figure S1 at $h t t p: / / a j p . a m j p a t h o l . o r g)$. With the exception of histones, none of these were identified in either total unfractionated proteins (see Supplemental Table S2 at $h$ ttp://ajp.amjpathol.org) or the $0.2 \mathrm{~mol} / \mathrm{L}$ fraction (see Supplemental Table S3 at http://ajp.amjpathol.org). Also prominently represented in DS-binding fraction was a large group of ribonucleoproteins, proteins related to the ribosome (including components of the large and small ribosomal subunits) and nucleolar proteins such as nucleolin (Table 2; see also Supplemental Appendix and references therein at http://ajp.amjpathol.org). In fact, these proteins were among the most abundant proteins extracted from WIL2-NS cells (see Supplemental Table S2 at $h$ ttp://ajp.amjpathol.org) and also highly abundant in DS-binding fractions. In particular, the Sm autoantigens (small nuclear ribonucleoproteins) were identified only in DS-binding fractions (Table 2; see also Supplemental Appendix and references therein at $h$ ttp://ajp.amjpathol. org), not in nonbinding or weakly binding fractions. Affinity to DS characterizes at least seven Sm autoantigens, including U2 snRNP-A', U2 snRNP-B", and Sm D2.

\section{Discussion}

Here and in our companion article ${ }^{11}$ we provide experimental support for the hypothesis that complexation of a self-molecule with the glycosaminoglycan DS promotes specific B-1a cell responses and autoantibody production, thus rendering the self-molecule autoantigenic. Using proteome fractionation as a physicochemical selection mechanism for interrogating affinity to DS, we identified 246 distinct proteins (eluting at $\geq 0.4 \mathrm{~mol} / \mathrm{L}$ $\mathrm{NaCl}$; Tables 1 and 2; see also Supplemental Appendix and references therein at http://ajp.amjpathol.org), of which at least 147 (59.8\%) are previously well-known autoantigens or closely related to known autoantigens. It is likely that the remaining proteins contain additional autoantigens yet to be recognized as such. If weakly DS-binding proteins are included (ie, eluting at $0.2 \mathrm{~mol} / \mathrm{L}$ $\mathrm{NaCl}$; see also Supplemental Table S3 at http://ajp. amjpathol.org), the above numbers become 357 (DSbinding proteins) and 191 (known autoantigens), respectively. It has been estimated that the autoantigen-ome represents $\sim 1 \%$ of all human proteins (ie, approximately 200 to 300 individual autoantigens). ${ }^{2}$ This means that
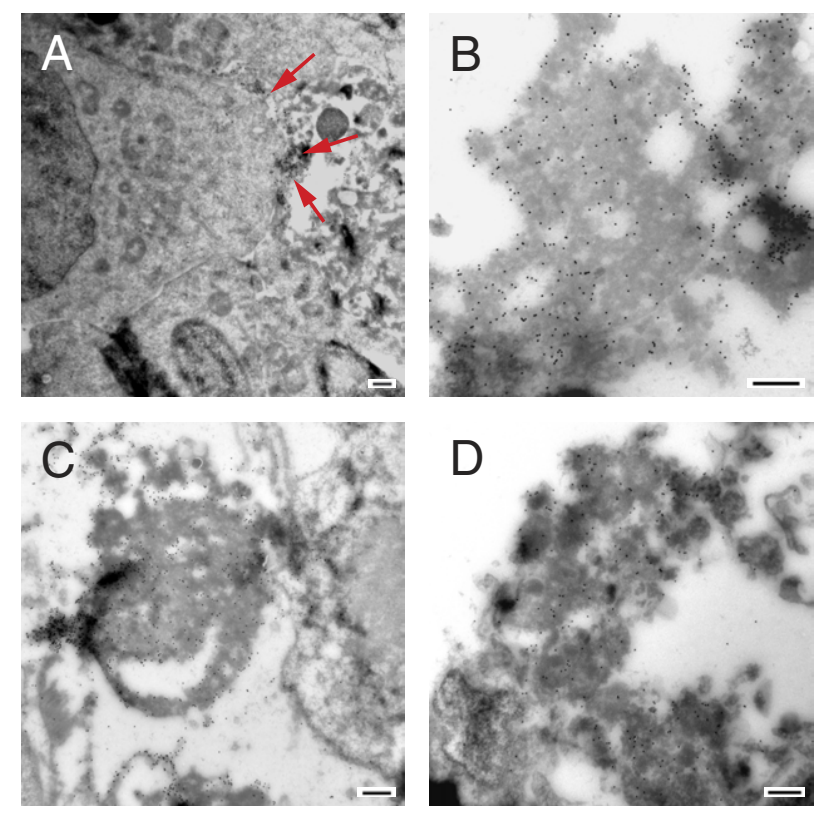

Figure 3. Direct association of DS with dead WIL2-NS cells. WIL2-NS cells were cultured with DS-biotin for 1 day to 3 days, and frozen sections of cells were labeled with anti-biotin gold particle conjugates (diameter, 20 $\mathrm{nm}$ ) for examination by electron microscopy. A: DS (small dots) associated with dead cell debris (arrows) just outside a viable cell (visible to the left). B: Higher magnification showing DS association with cell debris. C: DS associated with fibrillar membrane-type cell debris. D: DS associated with dead cell blebs. Note part of a dead cell nucleus (left bottom corner). Scale bar $=500 \mathrm{~nm}$ (all panels).

physicochemical association with DS may capture virtually the entire autoantigen-ome in a single step.

We first tested this hypothesis focusing on well-characterized ANA/ENA autoantigens (Figure 1; see also Supplemental Figure S1 at http://ajp.amjpathol.org). All tested ANA and ENA autoantigens were enriched in DSbinding fractions, and some, such as PCNA, were detectable only after DS-affinity enrichment. We then investigated the utility of DS-affinity enrichment for the characterization of autoantigen repertoires in human autoimmune disease (Figure 2; see also Supplemental Figure S3 at http://ajp.amjpathol.org). The experiments revealed the clinical presence of autoantibodies to many more autoantigens than previously thought and conventionally assayed for. Autoimmune diseases remain among the most poorly defined medical conditions. Both the complexity and the diversity of the patient-specific autoantigen profiles further attest to the challenge of precisely classifying these diseases, even in those that are traditionally considered one clinical entity, such as SLE. In fact, it seems attractive to envision both personalized classification and management of autoimmune conditions based on comprehensive autoantibody/autoantigen profiling and time-course evolution.

We next attempted to comprehensively characterize the set of all autoantigens with affinity to DS. The 46 proteins identified by sequencing of selected bands or spots from 1-D and 2-D gels proved to be either known autoantigens or closely associated with autoimmunity (Table 1; see also Supplemental Appendix and references therein at $h$ ttp://ajp.amjpathol.org). Extension to un- 
biased mass spectrometric shotgun sequencing identified a set of $>200$ proteins that are dominated by autoantigens (Table 2; see also Supplemental Appendix and references therein at $h t t p: / / a j p . a m j p a t h o l . o r g)$. Notably, the autoantigen-ome comprising approximately 200 autoantigens identified by DS-affinity fractionation is highly consistent with the estimated total human autoantigen repertoire. ${ }^{2}$ All major classes of autoantigens, such as ANA, ENA, cytoskeletal components, and heat shock proteins, were identified.

A significant portion of DS-binding (especially tightly binding) proteins are components of chromatin or ribonucleoproteins (ie, molecules associated with DNA or RNA). DS resembles DNA and RNA, in that all three are densely anionic polymers. From this, one may speculate that DS can compete with DNA or RNA and become associated with proteins via their DNA- or RNA-binding surfaces. Furthermore, it is possible that DS can bind autoantigens at other sites as well. For example, we found evidence that Scl-70 can bind DS and DNA simultaneously in a ternary complex (Figure 1B). If autoantigens are binding partners for polyionic molecules, it might explain why autoantigens frequently possess long chains of charged residues. ${ }^{9}$

Another class of autoantigens identified in this study consists of components of the cytoskeleton, including actin, vimentin, tubulin, spectrin, and actinin. Autoantibodies to the cytoskeleton, targeting microtubules, microfilaments, or intermediate filaments, have been found in a diverse spectrum of diseases. ${ }^{2}$ Glycosaminoglycans are known to be a major component of extracellular matrices, and it will be interesting to investigate whether DS and/or other glycosaminoglycans can associate intracellularly with the cytoskeleton or nuclear matrix, depending on physiological or pathogenic stimuli.

Although in the present study we focused on DS-binding autoantigen identification from affinity fractionated proteomes, autoantigens may not necessarily be in direct physical contact with DS. They may bind to DS directly or indirectly via one or more DS-binding scaffold molecules in a multimolecular complex. We speculate that some of the proteins eluted with lower concentrations of $\mathrm{NaCl}$ (eg, $0.2 \mathrm{~mol} / \mathrm{L}$ ) could be associated with DS via a protein that is eluted at higher salt concentration (eg, $1.0 \mathrm{~mol} / \mathrm{L}$ ). Although tightly DS-binding proteins are primarily chromatin-related proteins, ribonucleoproteins, or cytoskeletal proteins, those with lower DS affinity contain a set of enzymes that may in turn be associated with proteins that are tightly associated with DS.

With respect to the pathophysiologic role of DS•autoantigen association, we show in the companion article that DS preferentially associates with dead or apoptotic cells in murine models. ${ }^{11}$ This also holds for human WIL2-NS cells (Figure 3). As shown by electron microscopy, DS preferentially associates with dead cells or cell debris, supporting the notion that dead cells serve as a source of autoantigens. ${ }^{6,11}$

In the companion study, we further show in both cell culture and in mice that DS•antigen complexes promote robust Ig responses to an antigen but not to DS. ${ }^{11}$ To test whether this is also the case in humans, we measured
DS-specific IgG and IgM in patient sera. Indeed, all patients had very low levels of IgM or IgG against DS (see Supplemental Figure S6 at $h t t p: / / a j p . a m j p a t h o l . o r g)$. Total IgM ranged from $0.3 \mathrm{mg} / \mathrm{mL}$ to $2.8 \mathrm{mg} / \mathrm{mL}$, whereas DSspecific lgM ranged from $0.2 \mu \mathrm{g} / \mathrm{mL}$ to $3.4 \mu \mathrm{g} / \mathrm{mL}$, accounting for approximately $0.1 \%$ of total IgM (see Supplemental Figure S6A at $h$ ttp://ajp.amjpathol.org). Similarly, total IgG ranged from $7 \mathrm{mg} / \mathrm{mL}$ to $42 \mathrm{mg} / \mathrm{mL}$, whereas DS-specific IgG ranged from $0.4 \mu \mathrm{g} / \mathrm{mL}$ to $1.9 \mu \mathrm{g} / \mathrm{mL}$, accounting for $<0.05 \%$ of total $\lg \mathrm{G}$ (see Supplemental Figure S6B at $h$ ttp:// ajp.amjpathol.org).

Abnormal glycosaminoglycan metabolism has been observed in numerous autoimmune conditions. ${ }^{19,20}$ It is possible that DS production is increased during high cell turnover (eg, increased cell apoptosis in SLE) or with increased cell regeneration, turnover, and dead cell removal during wound healing. DS shares structural similarities with other endogenous and exogenous glycosaminoglycans, including heparin, heparan sulfate, and hyaluronic acid. DS also shares structural features with dextran sulfate, a known B cell mitogen. ${ }^{21}$ Furthermore, as a member of the polysaccharide family, DS mimics in various structural aspects polysaccharides that are expressed abundantly on the cell surfaces of microbial pathogens. ${ }^{22}$ Is it therefore possible that autoimmune diseases can be triggered by microbial infections through interaction of host molecules with microbial polysaccharides.

In sum, the present findings suggest affinity to DS as a unifying physicochemical property of human autoantigens and as a powerful and novel approach for the enrichment, identification, and near-complete characterization of the entire human autoantigen-ome, thus providing a promising method for the molecular stratification of clinically similar autoimmune diseases.

\section{Acknowledgments}

We thank Jongmin Lee, Ph.D., Ming Yan, Ph.D., Serena Leone, Ph.D., and Sidney Wang, Ph.D. (all at Harvard Medical School), for insightful discussions. We thank Ross Tomaino, Ph.D., and Steven Gygi, Ph.D., (Taplin Biological Mass Spectrometry Facility, Harvard Medical School) and Maria Ericsson (electron microscopy facility, Harvard Medical School) for expert assistance.

\section{References}

1. Plotz PH: The autoantibody repertoire: searching for order. Nat Rev Immunol 2003, 3:73-78

2. Amital $H$, Shoenfeld $Y$ : Natural autoantibodies, heralding, protecting and inducing autoimmunity. Autoantibodies, ed 2. Edited by $Y$ Shoenfeld, ME Gershwin, PL Meroni. Amsterdam, Elsevier, 2007, pp 7-12

3. Gilbert D, Brard F, Jovelin F, Tron F: Do naturally occurring autoantibodies participate in the constitution of the pathological B-cell repertoire in systemic lupus erythematosus? J Autoimmun 1996, 9:247-257

4. Fairweather D, Frisancho-Kiss S, Rose NR: Sex differences in autoimmune disease from a pathological perspective. Am J Pathol 2008, 173:600-609

5. Cohen PL, Maldonado MA: Animal models for SLE. Curr Protoc Immunol 2003, Chapter 15:Unit 15.20 
6. Casciola-Rosen L, Andrade F, Ulanet D, Wong WB, Rosen A: Cleavage by granzyme $B$ is strongly predictive of autoantigen status: implications for initiation of autoimmunity. J Exp Med 1999 190:815-826

7. Fourneau JM, Bach JM, van Endert PM, Bach JF: The elusive case for a role of mimicry in autoimmune diseases. Mol Immunol 2004, 40: 1095-1102

8. Powell AM, Black MM: Epitope spreading: protection from pathogens, but propagation of autoimmunity? Clin Exp Dermatol 2001, 26:427-433

9. Dohlman JG, Lupas A, Carson M: Long charge-rich alpha-helices in systemic autoantigens. Biochem Biophys Res Commun 1993, 195: $686-696$

10. Nozawa K, Fritzler MJ, Chan EK: Unique and shared features of Golgi complex autoantigens. Autoimmun Rev 2005, 4:35-41

11. Wang JY, Lee J, Yan M, Rho J, Roehrl MHA: Dermatan sulfate interacts with dead cells and regulates $\mathrm{CD}^{+} \mathrm{B}$-cell fate: implication for a key role in autoimmunity. Am J Pathol 2011, 178:2168-2176

12. Shevchenko A, Wilm M, Vorm O, Mann M: Mass spectrometric sequencing of proteins silver-stained polyacrylamide gels. Anal Chem 1996, 68:850-858

13. Peng J, Gygi SP: Proteomics: the move to mixtures. J Mass Spectrom 2001, 36:1083-1091

14. Damoiseaux JG, Tervaert JW: From ANA to ENA: how to proceed? Autoimmun Rev 2006, 5:10-17

15. Nojima J, Iwatani $Y$, Ichihara K, Tsuneoka H, Ishikawa T, Yanagihara M, Takano $T$, Hidaka $Y$ : Acquired activated protein $C$ resistance is associated with IgG antibodies to protein $S$ in patients with systemic lupus erythematosus. Thromb Res 2009, 124:127-131

16. Lu J, Willis AC, Sim RB: A calreticulin-like protein co-purifies with a '60 kD' component of Ro/SSA, but is not recognized by antibodies in Sjögren's syndrome sera. Clin Exp Immunol 1993, 94: $429-434$

17. McCauliffe DP, Yang YS, Wilson J, Sontheimer RD, Capra JD: The 5 '-flanking region of the human calreticulin gene shares homology with the human GRP78, GRP94, and protein disulfide isomerase promoters. J Biol Chem 1992, 267:2557-2562

18. Chan EK, Sullivan KF, Tan EM: Ribonucleoprotein SS-B/La belongs to a protein family with consensus sequences for RNA-binding. Nucleic Acids Res 1989, 17:2233-2244

19. Edward M, Fitzgerald L, Thind C, Leman J, Burden AD: Cutaneous mucinosis associated with dermatomyositis and nephrogenic fibrosing dermopathy: fibroblast hyaluronan synthesis and the effect of patient serum. Br J Dermatol 2007, 156:473-479

20. Parildar Z, Uslu R, Tanyalcin T, Doganavsargil E, Kutay F: The urinary excretion of glycosaminoglycans and heparan sulphate in lupus nephritis. Clin Rheumatol 2002, 21:284-288

21. Aoyama E, Yoshihara R, Tai A, Yamamoto I, Gohda E: PKC- and PI3K-dependent but ERK-independent proliferation of murine splenic B cells stimulated by chondroitin sulfate B. Immunol Lett 2005, 99: 80-84

22. Choi YH, Roehrl MH, Kasper DL, Wang JY: A unique structural pattern shared by T-cell-activating and abscess-regulating zwitterionic polysaccharides. Biochemistry 2002, 41:15144-15151 